\title{
EFEKTIVITAS KINERJA KEUANGAN DALAM MENENTUKAN MODEL PREDIKSI PEMERINGKATAN SUKUK
}

\author{
Febrina Nur Ramadhani ${ }^{1}$, David Kaluge ${ }^{1}$ \\ ${ }^{1}$ Fakultas Ekonomi dan Bisnis, Universitas Brawijaya Malang \\ febrina.nr94@gmail.com \\ david.kaluge@gmail.com
}

\begin{abstract}
This study aims to analyze the effectiveness of financial performance in determining the prediction model for sukuk. The financial performance used in this study consists of leverage, liquidity, solvency, profitability, productivity and coverage ratio. Tests were carried out on 37 companies whose sukuk were registered with PT PEFINDO rating agencies and had financial statements in 2011-2018 using multiple discriminant analysis (MDA). The results show that financial performance can form a prediction model for sukuk with a model accuracy rate of $89.2 \%$. There are four financial performance variables that can form a prediction model, namely leverage with long term liabilities/total asset proxy, liquidity with the proxy of current assets/current liabilities, profitability with the proxy of operating income/sales, and coverage with proxy operating income/total liabilities.
\end{abstract}

Keywords: Multiple Discriminant Analysis; Financial Ratio; Sukuk

\begin{abstract}
ABSTRAK
Penelitian ini bertujuan untuk menganalisis tingkat efektivitas kinerja keuangan dalam menentukan model prediksi pemeringkatan sukuk. Kinerja keuangan yang digunakan pada penelitian ini terdiri atas rasio leverage, likuiditas, solvabilitas, profitabilitas, produktivitas, dan coverage. Pengujian dilakukan pada 37 perusahaan yang sukuknya terdaftar pada agen pemeringkat PT PEFINDO dan memiliki laporan keuangan pada tahun 2011-2018, dengan menggunakan analisis diskriminan berganda (MDA). Hasil penelitian ini menunjukkan bahwa kinerja keuangan dapat membentuk model prediksi pemeringkatan sukuk dengan tingkat akurasi model mencapai 89,2\%. Ada empat variabel kinerja keuangan yang dapat membentuk model prediksi, yakni leverage dengan proksi long term liabilities/total aset, likuiditas dengan proksi current asset/current liabilities, profitabilitas dengan proksi operating income/sales, dan coverage dengan proksi operating income/total liabilitas.
\end{abstract}

Kata Kunci : Analisis Diskriminan Berganda; Rasio Keuangan; Sukuk

Jurnal Akun Nabelo: Jurnal Akuntansi Netral, Akuntabel, Objektif Volume 2/Nomor 1/Juli 2019 Jurusan Akuntansi FEB-Universitas Tadulako

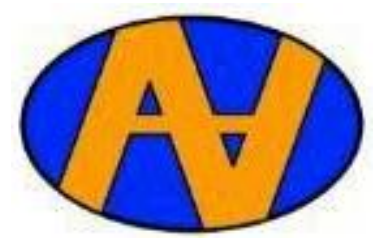




\section{A. PENDAHULUAN}

Seiring dengan perkembangan aktivitas ekonomi, variasi sumber pendanaan atas bisnis juga terus berkembang, salah satu diantaranya adalah obligasi syariah (sukuk). Berdasarkan Fatwa DSN No. 4 Tahun 2004 Tentang Obligasi Syariah Ijarah, obligasi syariah (sukuk) adalah suatu surat berharga jangka panjang berdasarkan prinsip syariah yang dikeluarkan oleh emiten kepada pemegang obligasi syariah yang mewajibkan emiten untuk membayar pendapatan kepada pemegang obligasi syariah berupa bagi hasil/marjin/fee dan membayar kembali dana obligasi pada saat jatuh tempo. Sebelum diterbitkan, sukuk biasanya akan diberikan peringkat oleh lembaga pemeringkat yang independen, objektif, dan dapat dipercaya. Peringkat obligasi merupakan skala risiko dari semua obligasi yang diperdagangkan. Skala ini menunjukkan tingkat keamanan suatu obligasi bagi investor, karena menunjukkan kemampuan emiten dalam melunasi pinjamannya (Tamara, 2013).

Di Indonesia, salah satu lembaga pemeringkat yang sering mengumumkan rating obligasi adalah PT Pefindo. Secara garis besar, PT Pefindo membagi peringkat sukuk menjadi dua kategori yakni kategori kuat dan lemah. Kategori kuat berada pada rentang peringkat AAA sampai BBB- yang berarti layak untuk didanai. Sedangkan, kategori lemah berada pada rentang peringkat $\mathrm{BB}+$ sampai D yang berarti tidak layak untuk dididanai. Namun, informasi atas faktor-faktor penentu peringkat sukuk oleh lembaga pemeringkat masih sangat terbatas. Padahal, informasi ini sangat penting bagi investor dalam pengambilan keputusan.

Beberapa penelitian telah dilakukan untuk mencari faktor-faktor yang dapat mempengaruhi peringkat obligasi (Asih, 2013; Denison, Yan, \& Zhao, 2007; Pandutama, 2012; Partha \& Yasa, 2016; Sari, 2007; Sarifuddin \& Mutmaimah, 2012; Tamara, 2013; Wescott, 2006). Berdasarkan beberapa penelitian tersebut diketahui bahwa faktor yang paling banyak digunakan untuk menilai peringkat obligasi adalah kinerja keuangan yang mana diukur menggunakan rasio keuangan. Signaling theory menjelaskan bahwa penerbitan laporan keuangan kepada pihak eksternal dikarenakan oleha adanya asimetri infromasi (Scott, 2009). Mengacu pada terori tersebut, laporan keuangan diharapkan dapat menjadi cerminanan atas kondisi suatu entitas, tidak terkecuali kemampuan dalam melunasi pinjaman. Hal ini yang mendasari penggunaan kinerja keuangan yang dapat dilihat dari laporan keuangan dalam memprediksi peringkat obligasi. Akan tetapi, beberapa penelitian tersebut masih berfokus pada obligasi non-syariah.

Salah satu yang menggunakan obligasi syariah sebagai objek penelitian adalah Tamara (2013). Penelitian tersebut melakukan analisis terhadap model prediksi pemeringkatan obligasi syariah menggunakan rasio keuangan. Dari penelitian tersebut diperoleh informasi bahwa rasio keuangan dapat digunakan dalam menentukan model prediksi pemeringkatan obligasi syariah. Namun, penelitian tersebut hanya dilakukan dalam rentang waktu tiga tahun. Selanjutnya, dengan mereplikasi model penelitian Tamara (2013), penelitian ini juga menggunakan rasio-rasio keuangan dalam melakukan analisis, yakni rasio rasio leverage, likuiditas, solvabilitas, profitabilitas, dan produktivitas. Sementara itu, untuk menyempurnakan keterbatasan pada penelitian tersebut maka terdapat satu variabel independen yang menjadi variabel tambahan pada peneltian ini, yakni rasio coverage. Rasio ini digunakan untuk mengukur kemampuan entitas dalam membayar utang, dengan asumsi semakin tinggi rasio coverage maka semakin besar kemungkinan pembayaran utang dapat dilakukan. Oleh karena itu, rasio ini juga perlu diperhatikan dalam memprediksi peringkat sukuk. Sedangkan untuk peringkat sukuk, penelitian ini menggunakan peringkat sukuk kategori kuat (AAA sampai BBB) sesuai dengan saran kelayakan investasi yang diberikan oleh PT Pefindo. Selain itu, untuk memperkuat hasil, periode penelitian juga diperpanjang menjadi tujuh tahun, yakni tahun 2012 sampai 2018. Berdasarkan pada latar belakang tersebut, maka penelitian ini bertujuan untuk untuk menganalisis model pemeringkatan sukuk melalui kinerja keuangan. 


\section{B. METODE PENELITIAN}

Penelitian ini dilakukan pada perusahaan yang sukuknya terdaftar pada agen pemeringkat PT Pefindo pada tahun 2012 sampai 2018. Data yang digunakan merupakan data sekunder berupa peringkat sukuk yang dirilis oleh PT Pefindo dan laporan keuangan (neraca, laba rugi, arus kas). Data bersumber dari website resmi PT Pefindo serta laporan keuangan perusahaan sampel. Pada penelitian ini digunakan varibel dependen dan variabel independen. Variabel dependen berupa peringkat sukuk yang tergolong dalam kategori kuat (Tabel 1).

Tabel 1

Pengelompokan Peringkat Sukuk

\begin{tabular}{|c|c|c|}
\hline Skor & Kategori & Rentang Peringkat \\
\hline 4 & AAA & AAA \\
\hline 3 & AA & AA+ sampai AA- \\
\hline 2 & A & A+ sampai A- \\
\hline 1 & B & BBB+ sampai BB- \\
\hline
\end{tabular}

Kategori kelompok harus dipersempit untuk memperjelas jarak antar kelompok, sehingga menghindari bias yang mungkin terjadi pada saat pengujian. Selanjutnya, variabel independen yang digunakan terdiri atas enam rasio keuangan, yakni sebagai berikut:

1. Rasio leverage, diproksikan dengan long term liabilities/total asset.

2. Rasio likuiditas, diproksikan dengan current asset/current liabilities.

3. Rasio solvabilitas, diproksikan dengan cash flow from operating/total liabilities.

4. Rasio profitabilitas, diproksikan dengan operating income/sales.

5. Rasio produktivitas, diproksikan dengan sales/total asset.

6. Rasio coverage, diproksikan dengan operating income/total liabilities.

Pengujian hipotesis dilakukan dengan menggunakan teknik multiple discriminant analysis (MDA). Dengan menggunakan MDA, variabel independen akan diuji dan diseleksi dengan metode stepwise sehingga diperoleh model yang paling tepat untuk memprediksi peringkat sukuk. Variabel independen yang masuk ke dalam seleksi SPSS akan menjadi persamaan fungsi diskriminan sebagai model prediksi yang terbentuk.

\section{HASIL DAN PEMBAHASAN}

\section{C.1. Deskripsi Obyek Penelitian}

Populasi pada penelitian ini terdiri dari 107 sukuk perusahaan. Pemilihan sampel dilakukan dengan metode purposive sampling, agar diperoleh sampel yang representatif sesuai dengan kriteria yang ditentukan. Beberapa syarat yang harus dipenuhi dalam memilih sampel, antara lain:

1. Bukan termasuk perusahaan di bidang jasa keuangan.

2. Memiliki laporan keuangan pada rentang tahun 2011 sampai 2017.

3. Memiliki peringkat sukuk yang termasuk dalam kategori kuat.

Berdasarkan syarat tersebut, terdapat 38 sampel yang memenuhi syarat untuk diuji dengan komponen masing-masing peringkat sebagai berikut.

Tabel 2

Pengelompokan Peringkat Sukuk

\begin{tabular}{|c|c|}
\hline Kategori & Jumlah Sukuk Sampel \\
\hline AAA & 11 \\
\hline AA & 8 \\
\hline A & 18 \\
\hline B & 1 \\
\hline
\end{tabular}

Penggunaan metode analisis MDA mengakibatkan kelompok BBB tidak dapat digunakan dalam pengujian hipotesis. Hal ini disebabkan oleh kelompok ini hanya terdiri dari 1 anggota kelompok saja. Sehingga, data yang digunakan dalam pengujian hipotesis hanya berjumlah 37 data. 


\section{C.2. Hasil Pengujian Hipotesis}

Berdasarkan hasil pengolahan data melalui SPSS dengan teknik Multiple Discriminant Analysis (MDA) diperoleh hasil sebagai berikut.

Tabel 3

Tests of Equality of Group Means

\begin{tabular}{|l|r|r|r|r|r|}
\hline & \multicolumn{1}{|c|}{$\begin{array}{c}\text { Wilks' } \\
\text { Lambda }\end{array}$} & \multicolumn{1}{c|}{$\mathrm{F}$} & \multicolumn{1}{c|}{ df1 } & \multicolumn{1}{c|}{ df2 } & \multicolumn{1}{c|}{ Sig. } \\
\hline Laverage & .638 & 9.637 & 2 & 34 & .000 \\
Likuiditas & .700 & 7.291 & 2 & 34 & .002 \\
Solvabilitas & .932 & 1.234 & 2 & 34 & .304 \\
Profitabilitas & .841 & 3.215 & 2 & 34 & .053 \\
Produktivitas & .570 & 12.829 & 2 & 34 & .000 \\
Coverage & .570 & 12.840 & 2 & 34 & .000 \\
\hline
\end{tabular}

Tabel 3 menggambarkan kelayakan variabel independen untuk didiskriminasi. Pada tabel tersebut dapat dilihat bahwa terdapat lima variabel independen yang memiliki tingkat signifikansi maksimum 0,05, yakni leverage, likuiditas, profitabilitas, produktivitas, dan coverage. Hal ini berarti bahwa berdasarkan data yang digunakan hanya kelima variabel tersebut yang dapat didiskriminasi. Variabel solvabilitias tidak akan digunakan pada pengujian lebih lanjut sebagaimana yang tertera pada Tabel 4.

Tabel 4

Variables Entered/Removed ${ }^{a, b, c, d}$

\begin{tabular}{|c|c|c|c|c|c|c|c|c|c|}
\hline \multirow[b]{3}{*}{ Step } & \multirow[b]{3}{*}{ Entered } & \multicolumn{8}{|c|}{ Wilks' Lambda } \\
\hline & & \multirow[b]{2}{*}{ Statistic } & \multirow[b]{2}{*}{ df1 } & \multirow[b]{2}{*}{ df 2} & \multirow[b]{2}{*}{ df3 } & \multicolumn{4}{|c|}{ Exact $\mathrm{F}$} \\
\hline & & & & & & Statistic & df1 & df2 & Sig. \\
\hline 1 & Coverage & .570 & 1 & 2 & 34.000 & 12.840 & 2 & 34.000 & .000 \\
\hline 2 & Laverage & .363 & 2 & 2 & 34.000 & 10.876 & 4 & 66.000 & .000 \\
\hline 3 & Likuiditas & .243 & 3 & 2 & 34.000 & 10.976 & 6 & 64.000 & .000 \\
\hline 4 & Profitabilitas & .190 & 4 & 2 & 34.000 & 10.037 & 8 & 62.000 & .000 \\
\hline
\end{tabular}

At each step, the variable that minimizes the overall Wilks' Lambda is entered.

a. Maximum number of steps is 12 .

b. Maximum significance of $F$ to enter is .05 .

c. Minimum significance of $\mathrm{F}$ to remove is 10 .

d. F level, tolerance, or VIN insufficient for further computation.

Pada tabel 4 dapat dilihat bahwa varibel solvabilitas sudah tidak digunakan lagi dalam pengujian lanjutan. Selain itu, terdapat satu variabel independen lagi yang tereduksi karena tidak memenuhi syarat nilai minimal signifikasi $\mathrm{F}$ sebesar 0,10, yakni variabel produktivitas. Sehingga, hanya terdapat empat variabel yang tersisa yakni coverage, leverage, likuiditas, dan profitabilitas dengan signifikansi 0,000. Artinya, berdasarkan data yang digunakan, hanya keempat variabel ini yang diapat digunakan untuk memprediksi peringkat sukuk. Urutan step pada tabel tersebut menjelaskan tentang kekuatan variabel dalam memprediksi. Sehingga, coverage memiliki kekuatan paling tinggi dalam memprediksi peringkat sukuk.

Selain itu, berdasarkan pengujian yang dilakukan juga diperoleh nilai wilks' lambda untuk dua fungsi yang terbentuk yakni sebesar 0,190 yang kemudian ditransfer menjadi chi-square sebesar 54 dengan tingkat signifikansi 0,000 atau lebih kecil dari 0,05, menggambarkan bahwa kedua fungsi yang dibentuk dapat melakukan fungsi diskriminan terhadap sampel. Selanjutnya, untuk memprediksi keanggotaan setiap objek pada analisis ini dapat dilihat dari peta teritorial. Peta teritorial memperlihatkan teritorial setiap grup. Keanggotaan 
diprediksi dengan tepat bila anggota grup masuk pada teritorial grupnya. Kemudian, persebaran data anggota grup dapat dilihat melalui scattergram (Gambar 1).

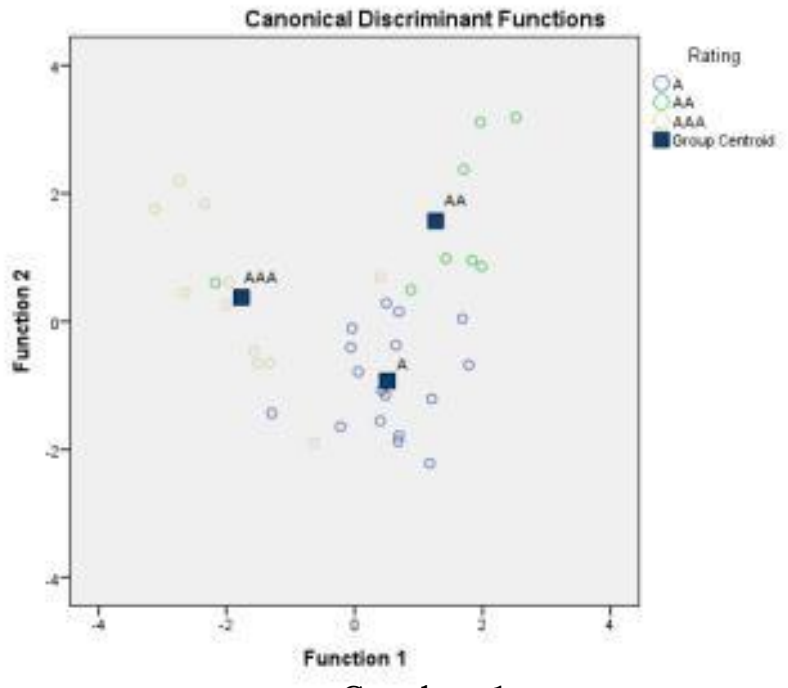

Gambar 1

Canonical Discriminat Functions

Asumsi yang digunakan pada gambar ini adalah semakin dekat titik sampel dengan grup centroid-nya (pusat kelompoknya) menandakan semakin kuat kemampuan variabel dalam menentukan kelompok. Sehingga, ketika centroid grup berada saling berdekatan, maka pembagian grup akan sulit untuk diprediksi. Penjelasan lebih lanjut atas Gambar 1 dapat dilihat pada Tabel 5.

Berdasarkan Tabel 5 diperoleh informasi bahwa keempat variabel yang digunakan pada penelitian ini mampu mengklasifikasikan kelompok dengan tingkat kekuatan $89,2 \%$. Hal ini dapat dibuktikan dengan sedikitnya jumlah data menyimpang, yakni berjumlah 4 data dari total 37 data yang digunakan.

\section{C.3. Pembahasan}

Berdasarkan pengujian hipotesis, diperoleh hasil bahwa secara garis besar, kinerja keuangan dapat digunakan untuk memprediksi peringkat sukuk. Hasil ini sesuai dengan hasil penelitian yang dilakukan oleh (Pandutama, 2012; Partha \& Yasa, 2016; Sari, 2007; Sarifuddin \& Mutmaimah, 2012). Hasil ini juga mengindikasikan bahwa kinerja keuangan yang diperoleh dari laporan keuangan dapat menjadi sarana memperkecil asimentri informasi. Sehingga dapat dikatakan bahwa hasil yang diperoleh mendukung signaling theory. Lebih lanjut, melalui analisis yang dilakukan juga dapat diketahui kemampuan masing-masing variabel yang digunakan dalam memprediksi peringkat sukuk.

Tabel 5

Classification Results ${ }^{\mathrm{a}}$

\begin{tabular}{|c|c|c|c|c|c|c|}
\hline & & \multirow[b]{2}{*}{ Rating } & \multicolumn{3}{|c|}{ Predicted Group Membership } & \multirow[b]{2}{*}{ Total } \\
\hline & & & A & $\mathrm{AA}$ & AAA & \\
\hline \multirow[t]{6}{*}{ Original } & \multirow[t]{3}{*}{ Count } & A & 17 & 0 & 1 & 18 \\
\hline & & AA & 0 & 7 & 1 & 8 \\
\hline & & AAA & 1 & 1 & 9 & 11 \\
\hline & \multirow[t]{3}{*}{$\%$} & A & 94.4 & .0 & 5.6 & 100.0 \\
\hline & & AA & .0 & 87.5 & 12.5 & 100.0 \\
\hline & & AAA & 9.1 & 9.1 & 81.8 & 100.0 \\
\hline
\end{tabular}

a. $89,2 \%$ of original grouped cases correctly classified.

Pertama, rasio leverage yang diproksikan dengan long term liabilities/total asset. Rasio ini digunakan untuk mengukur keseimbangan proporsi aset yang didanai oleh kreditor dan pemilik. Tingginya nilai rasio leverage mengindikasikan bahwa sebagian besar aset didanai dengan utang. Sehingga semakin tinggi rasio leverage, maka semakin besar pula risiko kebangkrutan 
(Hunt \& Duke, 1990). Dengan demikian, rasio leverage yang rendah memungkinkan peringkat sukuk yang tinggi. Sejalan dengan penelitian Partha \& Yasa (2016), hasil penelitian ini mendukung asumsi tersebut. Namun, bertentangan dengan hasil penelitian Asih (2013) yang menyatakan bahwa leverage tidak berpengaruh signifikan terhadap peringkat obligasi.

Kedua, rasio likuiditas yang diproksikan dengan current asset/current liabilities. Rasio ini digunakan untuk mengetahui kemampuan perusahaan dalam membayar kewajiban finansial jangka pendek secara tepat waktu. Semakin tinggi tingkat rasio likuiditas suatu perusahaan, maka semakin tinggi posisi likuiditas perusahaan tersebut. Hasil penelitian ini juga mendukung asumsi tersebut, yang berarti likuiditas perusahaan juga dapat digunakan untuk memprediksi peringkat sukuk (Asih, 2013).

Ketiga, rasio solvabilitas yang diproksikan dengan cash flow from operating/total libailities. Rasio ini digunakan untuk mengukur kemampuan perusahaan dalam memenuhi segala kewajiban finansialnya bila perusahaan tersebut dilikuidasi. Dengan kata lain, rasio solvabilitas merupakan kemampuan perusahaan dalam membayar semua kewajibannya baik jangka pendek maupun jangka panjang yang telah jatuh tempo (Horrigan, 2006). Namun, sejalan dengan penelitian (Tamara, 2013), hasil penelitian ini menunjukkan bahwa rasio solvabilitas tidak dapat digunakan dalam memprediksi peringkat sukuk.

Keempat, rasio profitabilitas yang diproksikan dengan operating income/sales. Rasio ini digunakan untuk mengetahui tingkat kinerja keuangan suatu perusahaan. Tingginya profitabilitas menunjukkan rendahnya kemungkinan ketidakmampuan perusahaan dalam memenuhi kewajibannya, sehingga peringkat sukuk atas perusahaan itu akan semakin baik. Asumsi tersebut terbukti pada penelitian ini. Sesuai dengan hasil penelitian Asih (2013) dan Tamara (2013), rasio solvabilitas dapat digunakan dalam memprediksi peringkat sukuk.

Kelima, rasio produktivitas yang diproksikan dengan sales/total asset. Rasio ini dapat digunakan untuk mengetahui seberapa efektif perusahaan mempergunakan sumber daya yang dimiliki. Hasil penelitian Horrigan (2006) menunjukkan bahwa rasio produktivitas secara signifikan berpengaruh positif terhadap peringkat obligasi. Namun, hasil berbeda ditunjukkan pada penelitian ini yang mana pada penelitian ini rasio produktivitias tidak dapat menentukan model prediksi peringkat sukuk.

Terakhir, rasio coverage yang diproksikan dengan operating income/total liabilities. Rasio ini digunakan untuk mengukur kemampuan entitas dalam membayar utang. Sesuai dengan asumsi yang dibangun, hasil analisis menunjukkan variabel ini memiliki kekuatan paling tinggi dalam menentukan model prediksi. Sehingga, secara keseluruhan diperoleh hasil, kinerja keuangan yang diukur melalui rasio leverage, likuiditas, profitabilitas, dan coverage dapat digunakan dalam menentukan model prediksi pemeringkatan sukuk dengan tingkat akurasi mencapai $89,2 \%$. Meskipun nilai ini lebih rendah dari penelitian Sari (2007) yang menunjukkan tingkat akurasi sebesar 96,9\%, serta Tamara (2013) dengan tingkat akurasi sebesar 94,3\%. Namun, temuan penelitian ini memiliki satu variabel tambahan yang juga dapat digunakan dalam memprediksi peringkat sukuk, yakni rasio coverage.

\section{KESIMPULAN}

Berdasarkan hasil pengujian yang dilakukan pada 37 sukuk perusahaan yang terdaftar di PT Pefindo dari tahun 2012 sampai tahun 2018, maka dapat disimpulkan bahwa kinerja keuangan dapat digunakan dalam menentukan model prediksi pemeringkatan sukuk. Kinerja keuangan yang dapat digunakan adalah rasio leverage yang diproksikan dengan long term liabilities/total asset; likuiditas dengan proksi current asset/current liabilities; profitabilitas dengan proksi operating income/sales dan coverage dengan proksi operating income/total liabilities. Penelitian selanjutnya dapat melakukan pengujian lebih lanjut terhadap dua variabel yang ditolak, yakni rasio solvabilitas dan rasio 
produktivitas. Hal ini dikarenakan belum diperoleh keseragaman hasil dengan beberapa penelitian sebelumnya. Hasil penelitian ini berkontribusi dalam membantu investor/kreditur menilai sukuk yang layak untuk didanai dengan memperhatikan rasio kinerja keuangan. Selain itu, hasil penelitian ini juga dapat menjadi masukan bagi perusahaan penerbit obligasi untuk memperbaiki kinerja keuangannya agar mudah memperoleh pendanaan dari luar.

\section{DAFTAR PUSTAKA}

Asih. 2013. Analisis Faktor-Faktor yang Mempengaruhi Prediksi Peringkat Obligasi Pada Perusahaan Non-Keuangan yang Terdaftar di BEI Periode 2011 - 2013. JOM Fekon.

Denison, D. V., Yan, W., \& Zhao, Z. J. 2007. Is Management Performance a Factor in Municipal Bond Credit Ratings? The Case of Texas School Districts. Public Budgeting and Finance. https://doi.org/10.1111/j.15405850.2007.00889.x

Fatwa DSN No. 4 Tahun 2004 Tentang Obligasi Syariah Ijarah. (n.d.).

Horrigan, J. O. 2006. The Determination of Long-Term Credit Standing with Financial Ratios. Journal of Accounting Research. https://doi.org/10.2307/2490168

Hunt, H. G., \& Duke, J. C. 1990. An empirical examination of debt covenant restrictions and accounting-related debt proxies. Journal of Accounting and Economics. https://doi.org/10.1016/0165-4101(90)90041-2

Pandutama, A. 2012. Faktor-Faktor yang Mempengaruhi Prediksi Peringkat Obligasi Pada Perusahaan Manufaktur di BEI. Jurnal Ilmiah Mahasiswa Akuntansi.

Partha, I. M. B., \& Yasa, G. W. 2016. Kemampuan Rasio Keuangan Dalam Memprediksi Peringkat Obligasi Pada Perusahaan Sektor Non Keuangan. E-Jurnal Akuntansi Universitas Udayana.

Sari, M. P. 2007. Kemampuan Rasio Keuangan Sebagai Alat Untuk Memprediksi Peringkat Obligasi (PT Pefindo). Jurnal Bisnis Dan Ekonomi.

Sarifuddin, F., \& Mutmaimah. 2012. Pengaruh Faktor Keuangan dan Non Keuangan Terhadap Peringkat Obligasi Di Bursa Efek Indonesia. Jurnal Manajemen Dan Akuntansi.

Scott, W. R. 2009. Financial Accounting Theory (7th ed.). Toronto: Pearson Prentice Hall.

Tamara, K. 2013. Analisis Model Prediksi Pemeringkatan Obligasi Syariah Perusahaan Dengan Pendekatan Rasio Keuangan Di Bursa Efek Indonesia. Jurnal Penelitian, 10(2). https://doi.org/10.28918/jupe.v10i2.362

Wescott, S. H. 2006. Accounting Numbers and Socioeconomic Variables As Predictors of Municipal General Obligation Bond Ratings. Journal of Accounting Research. https://doi.org/10.2307/2490722 